\title{
The side effect of Botulinum toxin A injection for position of the eyelid
}

\author{
Jan Krásný ${ }^{* *}$ and Josef Šach ${ }^{2}$ \\ ${ }^{1}$ Eye Clinic, Third Faculty of Medicine, Vinohrady Teaching Hospital, Charles University Prague, Czech Republic \\ ${ }^{2}$ Institute of Pathology, Third Faculty of Medicine, Vinohrady Teaching Hospital, Charles University, Prague, Czech Republic
}

\begin{abstract}
Authors report about a case illustrating the possibility of negative influence of repeated application of a derivate of Botulutoxin A on the eyelid position in older woman. The indication for successful surgical treatment was chronic entropium of lower lid. This was initially ineffectively treated by means of repeated intradermal injections of in this neurotoxin. Histological examination of the excised skin and subcutis samples taken during entropium plastic surgery showed unfavorable and irreversible changes including especially scarring of the eyelid and atrophy of the stripped muscles. Always we have to consider the frequency of application, because repeatedly used derivate of this neurotoxine causes irreversible changes in cutaneous and subcutaneous tissue.
\end{abstract}

\section{Introduction}

Botulotoxin is a natural bacterial toxin produced by the anaerobic spore-forming rod-shaped bacterium Clostridium botulinum. The actual effect resides in a blockade of the release of acetylcholine in the presynaptic membrane of the neuromusclar transmission, in other words a blockage of cholinergic neuromuscular transmission. This principle is used in the treatment of local muscular spasms. In addition to neurology, the principle of this blockage has been used also in ophthalmology, which was the pioneer of its use. At present the most widely used derivates of this neurotoxin remain Onabotulinumtoxin A $\left(\right.$ Botox $\left.^{\mathrm{R}}\right)$ and Abobotulinumtoxin A (Dysport $\mathrm{t}^{\mathrm{R}}$ -

\section{Case report}

A 90-year old woman was examined at outpatient Eye Department of Ophthalmic Clinic of Faculty Hospital Královské Vinohrady in Prague for persisting entropium of the lower left eyelid (fig.1, left-hand) in April 2007. Repeated injections of Dysport ${ }^{R}$ were administered anamnestically over course of three years, only with temporary effect, as stated by the patient. This woman was well aware of this condition, since afflicted eye was dominant, visual acuity 0,25 with correction +10 $\mathrm{D}$ comb $+1, \mathrm{D}$ ax $120^{\circ}$ for postoperative aphakia. In the right eye the vision was decreased to hand movement in front of the eye because of severe amblyopia. Over the course of three applications from June 2003 to November 2005, 100 IU Dysport ${ }^{\mathrm{R}}$ was administered into lower eyelid in five points. A classic picture of involution entropium was found upon our initial examination, characterized by a spontaneous rolling over of the lower eyelid against the eye, which was not accompanied by spasm. Epiphora was only in connection with trichiasis. The condition was treated by plastic surgery of the lower eyelid with myrth cutting of the skin and subcutis down to the orbicular muscle, which underwent partial resection in the surface layers six months after the last application of Dysport ${ }^{\mathrm{R}}$. Three months after the surgery the position of the eyelid was normalized, and the condition was permanent.

\section{The results of histological examination}

The resected part of the skin and subcutis showed two types of pathological changes (Figure. 1, right-hand). The first type of change was uneven scarring of corium and adjacent subcutis, in places also with residual microscopic structures of non-specific granulation tissue and microscopic residua of haematoma, evidently originating in connection with previous injection application (Figure. 1, top). The second observed type of changes was atrophy of fascicles of the stripped muscle with attenuation of their individual fibres and secondary fibroproductive enlargenment of their interstitium (Figure. 1, down).

\section{Discussion}

The use of derivates of Botulotoxin A are at present being widely applied and enjoying a boom in modern industrial states primarily in the field of cosmetic medicine, which is very popular above all in the USA. Out of a total sum of 11 billion dollars spent clients in 2007, 3 billion alone was spent on the application of Botulotoxin A, primarily Botox ${ }^{\mathrm{R}}$ [1]. Wrinkles in the area of the forehead and periorbital region can be positively cosmetically influenced with use $B$ tox $^{\mathrm{R}}$, but this procedure is not approved by the FDA and considered to be off-label [2]. After local application there may appear local pain and haematomas, headache, ptosis of the upper eyelids and eyebrows and a range of further changes $[1,3]$. In the Czech study there was described irreversible atrophy of the stripped muscle of the eyelids in direct connection with application of a derivate of Botuloxin A. Details of this problem are described in the Archives of Czech and Slovac Ophthalmology of Society (www.

Correspondence to: Jan Krásný, Eye Clinic of Teaching Hospital Královské Vinohrady, 10034 Praha 10, Šrobarova 50, Czech Republic, Europe. E-mail: jan. krasny@fnkv.cz

Key words: Botulinum toxin A, entropium, side-efect

Received: November 29, 2017; Accepted: December 23, 2017; Published: December 26, 2017 

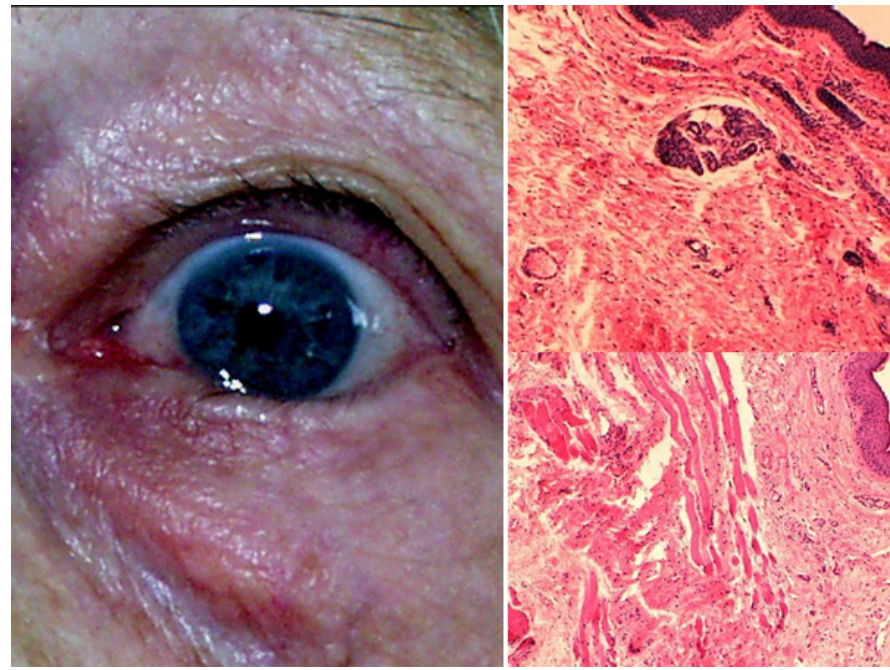

Figure 1. Entropium of the lower left eyelid (left) and scarring of eyelid on surface with non-specific granulation tissue (top), scarring and atrophy of muscle in eyelid (down), / colouring HE, enlargement 100x.

oftalmologie.com). At the same occasion, the identical authors report on an extensive literature analysis of positive and negative influence of this neurotoxine from the medical point of view [4].

FDA approved the application of a derivate of Botulotoxin A $\left(\right.$ Botox $\left.^{\mathrm{R}}\right)$ in 1989 in the indication of strabismus and blefarospasmus. Additional ophthalmic indications are not licensed. The first scientific publication on the clinical use of a derivate of Botulotoxin A in ophthalmology, dated 1980, is linked to the name of professor A.B. Scott [5], who used it in the treatment of strabismus as an alternative of the surgical procedure. It should be used under certain caution with regard to indications of its applications, since it has a more variable result than classic surgical treatment $[6,7]$. The secondary side effects such as above all vertical deviation, as well as ptosis etc. [8] are decisively in favour of a negative standpoint, $24 \%$ in the case of Dysport ${ }^{\mathrm{R}}$ and $55 \%$ in the case of Botox ${ }^{\mathrm{R}}$ [7]. Extensive studies about blepharospasm demonstrated a fundamentally positive therapeutic effect of a derivate of Botulotoxin $\mathrm{A}$ in the cases of this disorder, unlike previously used avulsion of the facial nerve $[9,10]$. A favorable effect of treatment was recorded in $57 \%$ of patients, whom a significant improvement was recorded in $44 \%$ [10]. All forms of injection products of Botulotoxin A remain a fundamental medicament for blepharospasm at the present time [11, 12].

\section{Conclusion}

The case-report draw attention to histologically verified adverse changes in the structure of eyelid following repeated application of a derivate of Botulotoxin A. Always we have to consider the frequency of application, because repeatedly used derivates of this neurotoxine may cause irreversible changes in cutaneous and subcutaneous tissue.

\section{References}

1. Niamtu J $3^{\text {rd }}$ (2009) Complications in fillers and Botox. Oral Maxillofac Surg Clin North Am 21: 13-21, v. [Crossref]

2. Klein AW (2004) Botox for the eyes and eyebrows. Dermatol Clin 22: 145-149, vi [Crossref]

3. Prager W, Huber-Vorländer J, Taufig AZ, Imhof M, Kühne U, et al. (2008) Botulinum toxin type A treatment to the upper face: retrospective analysis of daily practice. Clin. Cosmet. Investig. Dermatol. 5: 506 - 511. [Crossref]

4. Krásný J, Šach J (2012) The application of DysportR - the possibilities of the side effect on the eyelids position (clinical - Hstological study). Ces. a slov. Oftal. 68: 216-220.

5. Scott AB (1980) Botulinum toxin injections into extra-ocular muscles as an alternative to strabismus surgery. Ophthalmology 87: $1044-1049$. [Crossref]

6. Lueder GT, Galli M, Tychsen L, Yildirim C, Pegado V (2012) Long-term results of botulinum toxin-augmented medial rectus recessions for large-angle infantile esotropia. Am J Ophthalmol 153: 560-563. [Crossref]

7. Rowe FJ, Noonan CP (2012) Botulin toxin for the treatment of strabismus. Cochrane Database Syst Rev 15: CD006499. [Crossref]

8. Kowal L, Wong E, Yahalom C (2007) Botulinum toxin in the treatment of strabismus. A review of its use and effects. Disabil Rehabil 29: 1823-1831. [Crossref]

9. Elston JS, Russell RW (1985) Effect of treatment with botulinum toxin on neurogenic blepharospasm. Br Med J (Clin Res Ed) 290: 1857-1859. [Crossref]

10. Grandas F, Elston J, Quinn N, Marsden CD (1988) Blepharospasm: a review of 264 patients. J Neurol Neurosurg Psychiatry 51: 767-772. [Crossref]

11. Wabbels B, Reichel G, Fulford-Smith A, Wright N, Roggenkämper P (2011) Doubleblind, randomized, parallel group pilot study comparing two botulinum toxin type A products for treatment of blepharospasm. J Neural. Trans 118: 233 - 239. [Crossref]

12. Yoon JS, Kim JC, Lee SY (2009) Double-blind, randomized, comparative study of Medoxin versus Botox in the treatment of essential blepharospasm. Korean.J.Ophthalmol 23: 137 - 141. [Crossref]

Copyright: (C2017 Krásný J. This is an open-access article distributed under the terms of the Creative Commons Attribution License, which permits unrestricted use, distribution, and reproduction in any medium, provided the original author and source are credited. 